\title{
Sensitivity to environmental change of the treeline ecotone and its associated biodiversity in European mountains
}

\author{
F. E. Wielgolaski ${ }^{1, *}$, A. Hofgaard ${ }^{2}$, F. K. Holtmeier ${ }^{3}$ \\ ${ }^{1}$ Department of Bioscience, University of Oslo, PO Box 1066 Blindern, 0316 Oslo, Norway \\ ${ }^{2}$ Norwegian Institute for Nature Research, PO Box 5685 Sluppen, 7485 Trondheim, Norway \\ ${ }^{3}$ Institute of Landscape Ecology, Heisenbergstrasse 2, Westfälische Wilhelms-Universität, 48149 Münster, Germany
}

\begin{abstract}
Transition zones between mountain forests and treeless tundra, i.e. treeline ecotones, are characterized by great regional variety. In this paper, we discuss the biodiversity in various trophic levels in treeline ecotones throughout Europe, with particular focus on recent changes in land use and climate in northern and central mountains. In northernmost Europe, mountain birch prevails, while conifers (spruce, pine, larch) are the dominating species further south. While at continent-wide to global scales, the ecotone position is largely controlled by heat deficiency, it depends on a multitude of partly interacting abiotic and biotic factors other than climate at smaller scales. Climate change is a driving factor in treeline ecotone change, including physiognomic structure and biodiversity, although the effects of climate and other factors often overlap. Historical legacy plays an important role in this respect, and human impacts are particularly important. The recent decline in pastoral use of many European treeline areas often strongly influences plant diversity and re-growth of trees and other woody species. Climate change together with changing tree cover may influence snow cover, moisture regime, and nutrient conditions. Subsequently changed site conditions influence plant-plant interactions, favoring some species and disfavoring others, and plant-animal interactions. Native animals may cause widespread or local disturbances in treeline ecotone areas. Mass outbreaks of leaf-eating insects, for example, usually affect comparatively large forested areas whereas mammalian herbivores and birds have more local impact. However, high numbers of wild or domestic mammalian herbivores may challenge the carrying capacity of treeline ecotone areas at the same time as they preserve an open pasture character. This calls for cross-disciplinary study approaches, addressing the complexity of the ecotone regarding both causal background and biogeographic diversity.
\end{abstract}

KEY WORDS: Treeline ecotone $\cdot$ Ecotone change $\cdot$ Land use change Climate change . Animal impact

\section{INTRODUCTION}

Transition zones between mountain forests and treeless tundra, i.e. treeline ecotones, are characterized by great regional variety regarding abiotic and biotic components structuring the zone. Accordingly, due to environmental change and treeline shift, bio-

${ }^{*}$ Corresponding author: f.e.wielgolaski@ibv.uio.no diversity has been changing in the subalpine and lower alpine zone in many European mountains. In this paper, we discuss the biodiversity in various trophic levels in treeline ecotones throughout Europe, with particular focus on recent changes in land use and climate in northern and central mountains.

() The authors 2017. Open Access under Creative Commons by Attribution Licence. Use, distribution and reproduction are unrestricted. Authors and original publication must be credited. 


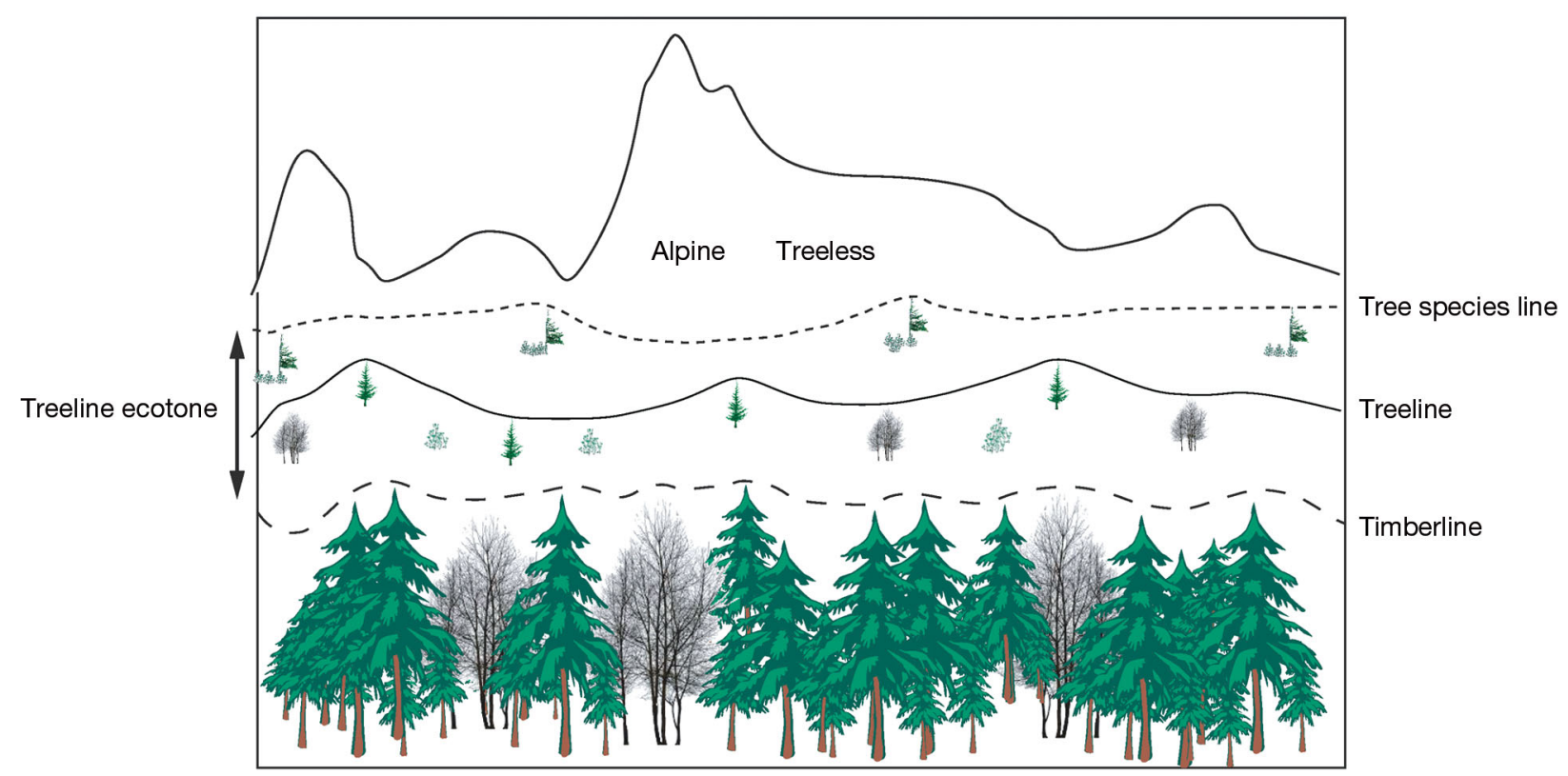

Fig. 1. Characteristics of the treeline ecotone

\subsection{Treeline ecotone}

The treeline ecotone spans the transition in decreased tree cover and tree height from the upper closed mountain forest to the treeless tundra. This transition boundary includes a number of tree status delineations (e.g. timberline, treeline, and tree species line; Fig. 1) used in studies of treeline ecotone dynamics. The definition of the ecotone and included lines may vary in the published literature (Callaghan et al. 2002a, Holtmeier 2009, Körner 2012, Irl et al. 2016, Holtmeier \& Broll 2017, this Special), but are commonly classified regarding causal background, to climatically, topographically, or anthropogenically defined ecotones and lines. The climatic treeline ecotone generally decreases in altitude from southern to northern mountains in Europe and is found from above $2000 \mathrm{~m}$ above sea level (a.s.l.) in southern Europe to close to sea level in the northernmost subarctic parts (Cudlín et al. 2017, this Special). The ecotone may be abrupt (e.g. in steep or heavily grazed areas), but is normally a relatively wide boundary, and may thus regionally cover a considerable area of the lower and most productive part of the alpine zone. The vastness of the treeline ecotone, and its conspicuous transition from tree-covered to treeless areas, makes it an important biogeographic component of region-wide ecological, climatic, and socioeconomic relevance (Callaghan et al. 2002b).

In northern Europe, both the alpine and arctic treeline ecotones are normally formed by mountain birch
Betula pubescens subsp. tortuosa (Ledeb.) Nyman (Wielgolaski 2001, 2005), but may regionally also include Norway spruce Picea abies L. and Scots pine Pinus sylvestris L. In mountains further south, the ecotone is normally formed by conifers such as spruce, pine (e.g. Pinus sylvestris, P. cembra L., P. uncinata Ramond ex DC.) and larch Larix decidua L., but regionally also beech Fagus sylvatica L. (Wilmanns 1989, Nagy et al. 2003, Holtmeier 2009 for ample references). In the upper part of the ecotone, trees become progressively more stunted and may form extensive areas with scattered individual krummholz or krummholz groups. In some mountain areas of Europe, the 'true krummholz' mountain pine Pinus mugo Turra, the usually prostrate and gnarled growth of which is genetically predetermined, dominates above the high-stemmed mountain forests (Holtmeier 1981, 2009).

Historically, extensive changes in the elevation of the treeline ecotone have occurred throughout Europe. For example, in both the Scandes and mountains further south, pollen analyses and radiocarbon dating of tree remains found in mires, alpine sediments, and at retreating glacier fronts have revealed that trees grew at much higher elevation during the early to mid-Holocene than today (Holtmeier 1974, 1993, 2009, Kullman 1995, 2004, Tinner et al. 1996, Allen \& Huntley 1999, Kullman \& Källgren 2000, Aas \& Faarlund 2001, Tinner \& Theurillat 2003, Heiri et al. 2006). During the late Holocene and until termination of the Little Ice Age (Grove 1988), treeline eco- 
tone retreat was the dominating trend in many European mountains (Karlén 1976, Shiyatov 1993, Kullman 1995). Later, the trend has reversed in response to both the release from the long-term climatic suppression during the Little Ice Age and the more recent climate warming (Kullman 1986, 2003, Gervais \& MacDonald 2000, Shiyatov 2003, Camarero \& Gutiérrez 2004, Motta et al. 2006). However, although an advancing trend is dominating, nonadvancing trends occur across European mountains (Harsch et al. 2009, Van Bogaert et al. 2011, Dinca et al. 2017, this Special).

In general, thermal deficiency during the growing season is a main factor limiting tree growth and development at high elevation, which has been well known since the beginning of treeline research. However, although southern slopes usually provide favorable thermal conditions, the treeline ecotone may be at a relatively low elevation due to moisture deficiency, as is the case in many summer-dry Mediterranean mountains (e.g. Brandes \& Ise 2007, Gonzáles de Andrés et al. 2015). Insufficient moisture supply as a result of summer drought also occurs at the treeline in Central Europe, as for example, in the Sudetes, where it affects tree seedling establishment on southern exposures (Treml \& Chuman 2015, Treml et al. 2016). Extreme winds, snow cover, wildfires, etc. may also influence tree growth in European treeline areas (Holtmeier \& Broll 2017). In addition, lowelevation ecotones may be due to historical and/or ongoing human activities, e.g. logging and pastoral use, creating anthropogenic elevation of the treeline ecotone. When landscape controlling pressures (e.g. human activities) cease or lessen, the response might be seen as a swift reforestation (Hofgaard 1997a, Bolli et al. 2007, Batllori \& Gutiérrez 2008, Bryn 2008). However, summer drought periods or other disturbances may affect tree growth and prevent or delay natural reforestation considerably (Hofgaard 1997a,b, Brandes \& Ise 2007, Grunewald \& Scheithauer 2008, Gonzáles de Andrés et al. 2015), due to the multitude of abiotic and biotic factors controlling changes in both structure and location of the treeline ecotone (Holtmeier \& Broll 2005, Hofgaard et al. 2012, Weisberg et al. 2013, Kulakowski et al. 2016).

The altitude of the treeline ecotone location decreases from central parts of mountain massifs to coastal areas. Central areas have a more continental climate due to protection from cool and moisturecarrying air masses, and thus, normally have higher daytime temperatures during the growing season, compared to heavily dissected and maritime mountain ranges. The 'mass elevation effect' (De Quervain
1904) often overlaps with the influence of the continental climate (Brockmann-Jerosch 1919, Turner 1961, 1970, Holtmeier 2009, Kašpar \& Treml 2016). In addition to the north-south and coast-inland gradients, mountain topography strongly influences ecotone elevation and spatial patterns at smaller scales (Holtmeier 2009, Holtmeier \& Broll 2010, 2012). This is most evident for steep slopes, where recurrent avalanches often prevent tree establishment and cause topographically defined ecotone location.

\subsection{Biodiversity}

Transition zones between 2 major biomes generally have high biodiversity. This also applies to the treeline ecotone compared to the forest at lower elevation and the treeless tundra at higher elevation (Hofgaard \& Wilmann 2002). High biodiversity in ecotones is mainly caused by an overlapping distribution of species originally belonging to the 2 adjoining biomes. In addition, as mountains are often characterized by a highly varying and rugged topography, the biological richness is high with strong differences occurring at short distances (Huston 1994). Further, a mix of vegetation-covered ground and open patches with high light intensity at the ground is characteristic of the treeline ecotone. Taken together, this provides a wide range of temperature- and moisture-defined microhabitats favorable to high species diversity (Körner 2003, Nagy \& Grabherr 2009).

Species richness across European treeline ecotones decreases with latitude, but depends on a large number of abiotic and biotic factors, such as human activities and soil conditions (Callaghan et al. 2004, Vittoz et al. 2010). However, the general trend with decreasing species diversity towards high latitudes or altitudes makes the ecotone an indistinct species boundary. A general decrease in species diversity is accompanied by a strong nutrient and productivity gradient (Callaghan et al. 2004), but there is a lack of evidence for a causal connection between latitudinal decrease in species diversity and productivity (Rohde 1992). This is evidenced by some species groups with a high frequency in the treeline ecotone showing a reversed latitudinal trend, such as willows, wasps, sawflies, aphids, and peatland birds, which has been related to habitat heterogeneity (Kouki 1999).

Scenarios for biodiversity change caused by human activity indicate land use as the most important driver for biodiversity changes in terrestrial ecosystems (Sala et al. 2000), which has strong relevance to 
the treeline ecotone. Changes in biodiversity affect the functioning of ecosystems, and thereby also society through many ecosystem services (Garcia-Ruiz et al. 1996, Cardinale et al. 2012; this Special: Sarkki et al. 2017a,b, Kyriazopoulos et al. 2017, Fleischer et al. 2017, Nijnik et al. 2017).

\section{CHANGES IN PLANT DISTRIBUTION}

Although changes in temperature and precipitation (including snow cover) surely alter treeline ecotone locations and species diversity, as apparent from the Holocene period and recent history (Kullman 1995, 2003, Aas \& Faarlund 1996, 2001, Körner 2003, Shiyatov 2003, Hofgaard et al. 2013, Mathisen et al. 2014, Schwörer et al. 2014), it has also been shown that land use changes may have stronger impact than climate change (Motta et al. 2006, Gehrig-Fasel et al. 2007, Aune et al. 2011, Callaghan et al. 2013, Grytnes et al. 2014, Strebel \& Bühler 2015). This is also indicated in reports from the present SENSFOR study (Sarkki et al. 2016, Cudlín et al. 2017, Kyriazopoulos et al. 2017).

In many parts of Europe, there is a long tradition of grazing cattle, sheep, and goats at and above the treeline. This allows forage around the farms at low elevation to be saved for the winter season (Holtmeier 1974, 1987, 2009, Bryn \& Daugstad 2001). In northern Europe, semi-domestic reindeer are similarly moved between alpine summer grazing areas and lower elevation winter grazing areas. Through time, this European-wide practice has created nonclimatic ecotone locations and diversity characteristics. Many different human activities has contributed to this throughout history (Emanuelsson 1987, Bryn \& Daugstad 2001, Gehrig-Fasel et al. 2007) and in more recent times, tourism and recreation has impacted the treeline ecotone vegetation to an increasing degree (Wielgolaski 1998, Körner 2003, Forbes et al. 2005, Törn et al. 2009, Rixen \& Rolando 2013, Sato et al. 2013, Tolvanen \& Kangas 2016, Ylisirniö \& Allén 2016). Activities with an impact across or directly below the treeline ecotones are, or have been, tree clearing for space, fire wood, fencing, and building purposes, and harvesting of young twigs and leaf material, particularly from deciduous trees, as additional fodder. Litter has been used for bedding in the cattle sheds. The magnitude of an impact is dependent on both direct human activities (e.g. cutting) and on grazer diversity and density (Fig. 2), and in addition, on the duration of summer grazing throughout history (Austrheim et al. 2008, Speed et al. 2010,
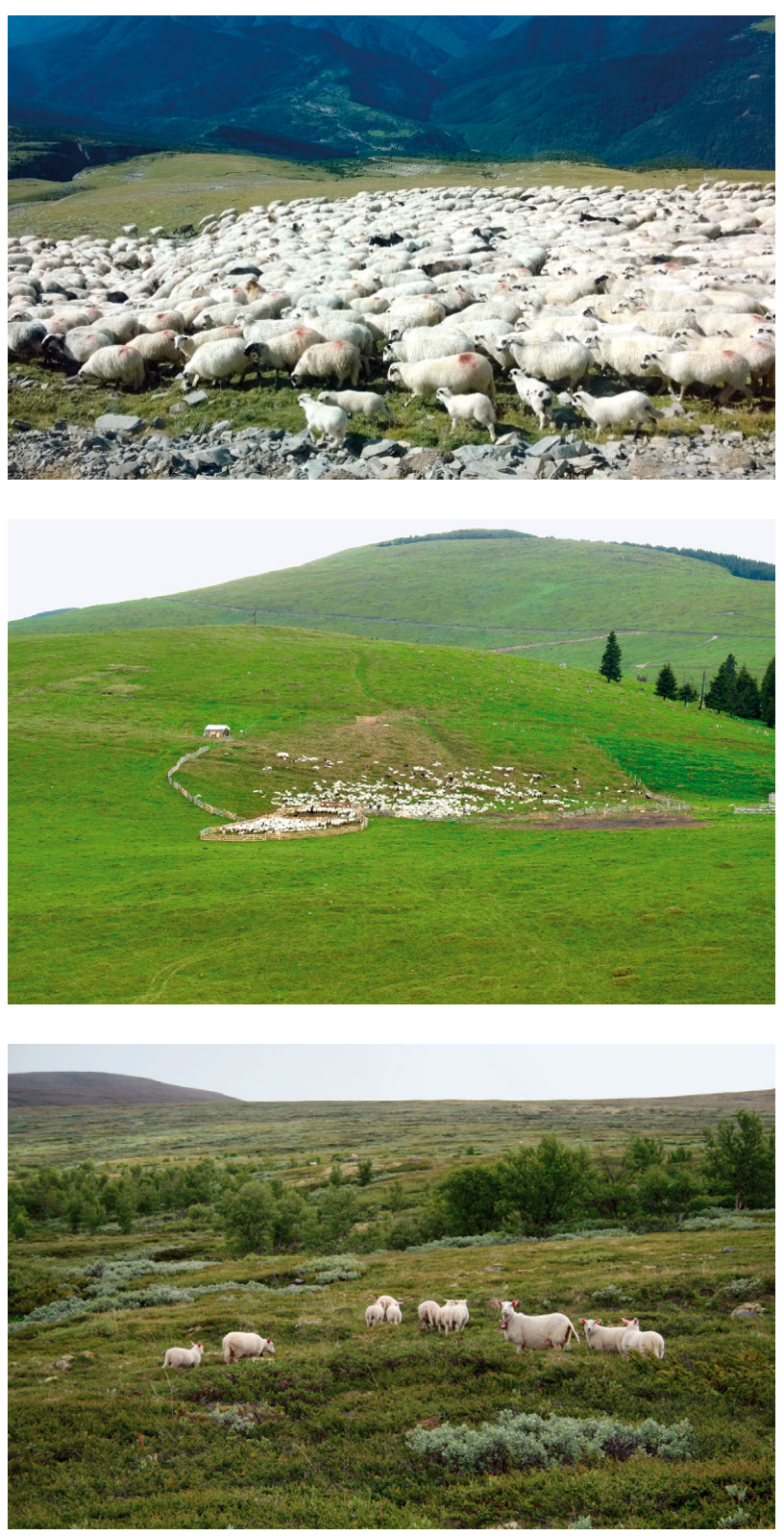

Fig. 2. Pasture husbandry may differ widely between European mountains. In southern and central Europe, sheep are generally kept in dense herds controlled by herders (upper panel), and gathered in fenced areas for the night to avoid carnivore predation (middle panel). In the Scandinavian mountains, a non-herding system is practiced which allows sheep to disperse over the landscape in small groups (lower panel) under occasional monitoring by owners. Upper panel: Pyrenees, Spain. Photography by J. Inkeröinen. Middle and lower panels: Rodnei Mountains, Carpathians, Romania and Dovre mountains, Norway. Photography by A. Hofgaard

2012). In some treeline areas, natural pastures have been cultivated, fertilized and sown with grass of non-alpine origin to increase the amount of the fodder (Fig. 3). These pasture management methods 


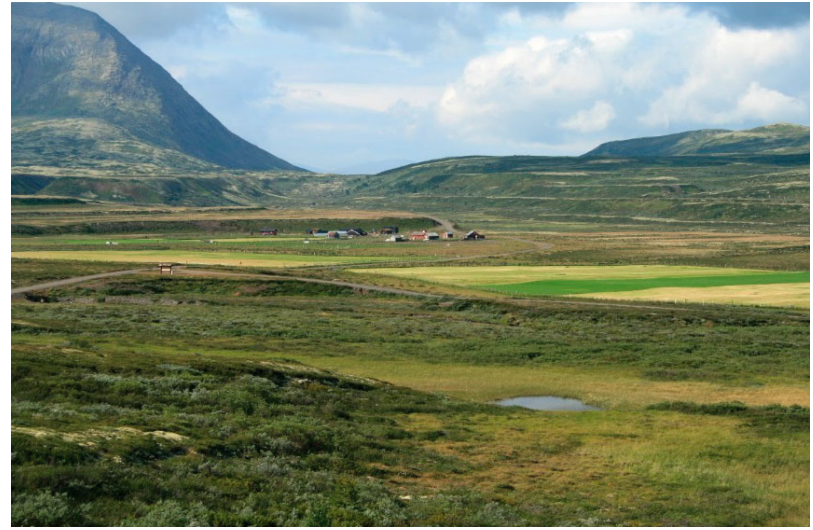

Fig. 3. Summer farm with grass production using non-alpine grass species and artificial fertilizers. Flåmsætrin, Central Norway. Photography by A. Hofgaard

have strongly influenced the natural vegetation. Lowland species, including anthropocores, brought to the treeline ecotone areas by these cultivation practices might cause an anomalous increase in species diversity in an area, at least locally and for a short period (Cudlín et al. 2017). However, these non-alpine species could linger in the area and become invasive in future favorable environmental conditions (Crooks \& Soulé 1999). As to novel competitive interactions, it may be essential to accurately predict plant species' responses to e.g. climate change (Hofgaard 1999, Alexander et al. 2015). The presence of potentially invasive species make any prediction difficult or impossible (Mooney \& Hofgaard 1999, Petitpierre et al. 2016).

During the last 50 to $100 \mathrm{yr}$, summer farming practice has become strongly reduced both in northern and more southern European mountain areas (Bryn \& Daugstad 2001, Tasser \& Tappeiner 2002, Camarero \& Gutiérrez 2007, Chauchard et al. 2007, Tasser et al. 2007, Batllori \& Gutiérrez 2008, Ameztegui et al. 2010, Treml et al. 2016). One reason is the increased importance of imported fodder due to its low cost, while at the same time, the labor-demanding traditional summer farming has become too costly. In some European mountains, however, such as the Alps, farmers are paid by the authorities (Fischer et al. 2008) to continue the traditional pastoral use of elevated mountain areas. This is intended to maintain the character and biodiversity of the cultural landscape that the alpine zone represents. However, in many European mountain areas, grazing by e.g. sheep, is still a normal land use form (Fig. 2), and in others, traditional land use is being replaced by use linked to winter and/or summer tourism (Fig. 4).
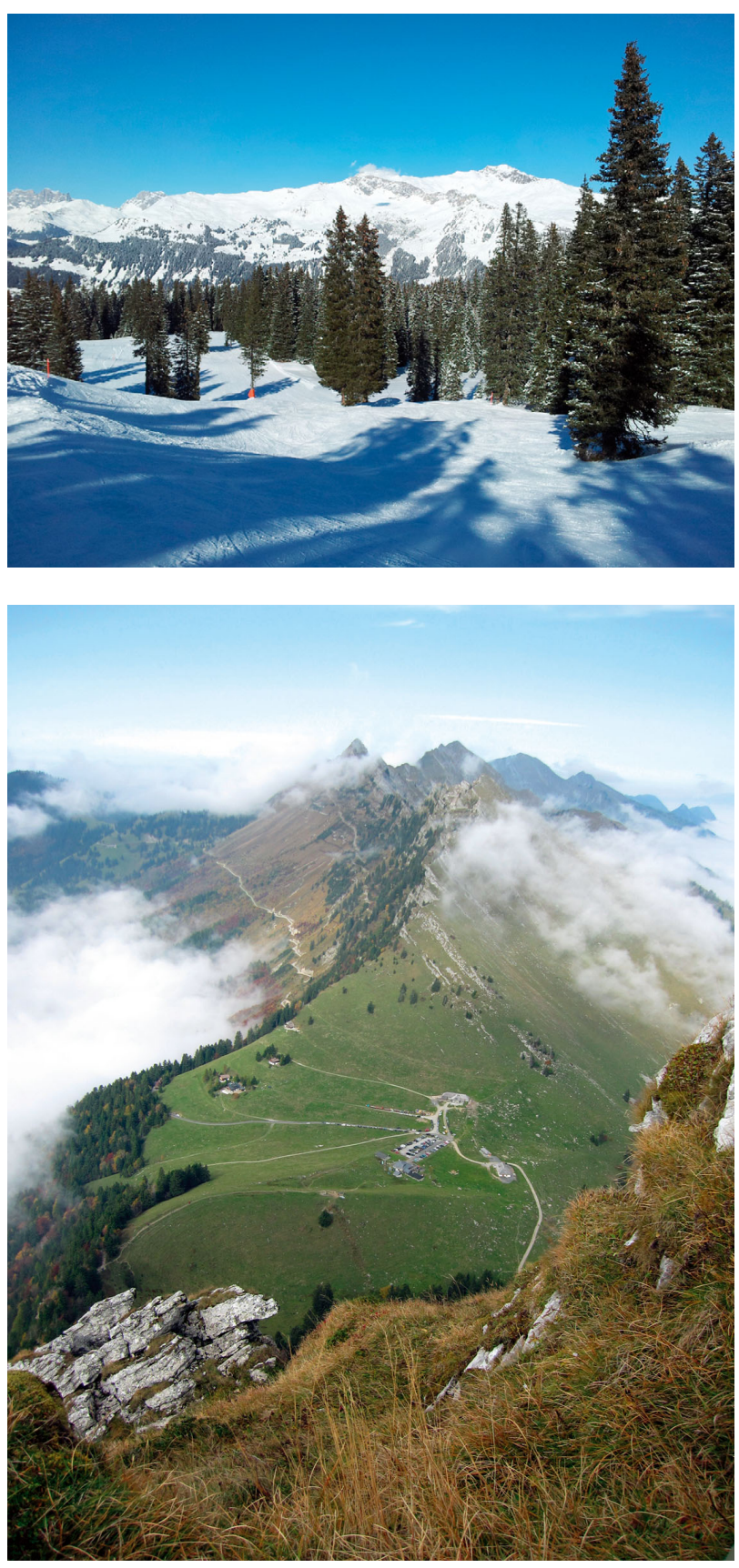

Fig. 4. In downhill ski areas, the upper part of the mountain forest and corridors through the forest are managed as open woodlands to favor ski tourism (upper panel: Klosters, Switzerland), and preservation of pastures in the treeline ecotone creates attractive areas for hiking tourism (lower panel: Jaman, Switzerland). Photography by A. Hofgaard

Abandonment or reduction of traditional pastoralism in treeline ecotone areas is normally followed by strong and very fast recolonization and growth of trees, shrubs, and other plant species palatable to domestic and semi-domestic animals. Biodiversity 
may increase at the early stages of recolonization of former alpine pasture (Strebel \& Bühler 2015, Cudlín et al. 2017), but then decrease at later stages due to growing tree and shrub populations outcompeting alpine pasture species (Holtmeier \& Broll 2017) (Fig. 5). This basically land use-driven process is evident both in the Scandes, where mountain birch quickly colonizes abandoned alpine pasture fields (Bryn 2008, Bryn \& Hemsing 2012, Bryn et al. 2013) (Fig. 6), and in more southern European mountains (Dirnböck et al. 2003, Gehrig-Fasel et al. 2007, Sitko \& Troll 2008), where e.g. mountain pine is an efficient colonizer (Fig. 7). However, in northern Fennoscandia, where reindeer husbandry prevails, temperature also appears to be an important factor directly (Karlsen et al. 2017, this Special). In addition, recent increased precipitation in northern regions (Hanssen-Bauer et al. 2015) might also have influenced mountain birch growth (Mathisen et al. 2014), as this species is favored by precipitation (Wielgolaski 2001, 2003, Wielgolaski \& Karlsen 2007). The increased growth observed in mountain birch in the Scandes might also indicate increased nutrient supply as a consequence of increased precipitation and temperature, and subsequent increased decomposition (Wielgolaski \& Nilsen 2001, Wielgolaski \& Karlsen 2007). Similarly, expansion of green alder Alnus viridis Chaix in the Alps as a result of reduced land management has an important influence on nitrogen conditions in former nitrogen-poor montane grasslands (Bühlmann et al. 2016). However, as observed in Swiss mountain grasslands, nitrogen deposition might be negatively related to species richness due

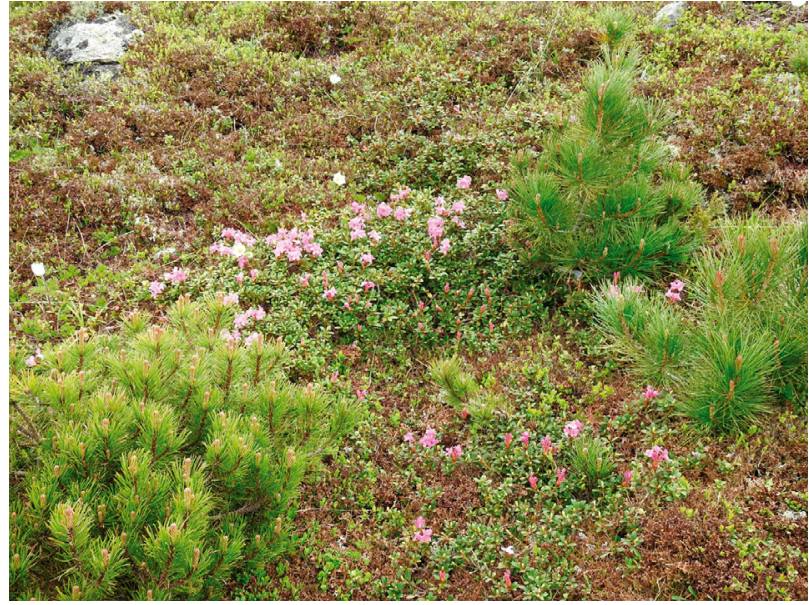

Fig. 5. Recruitment and spread of coniferous shrub (Pinus mugo, lower left) and tree (P. cembra, right) populations outcompeting alpine pasture species. Rodnei Mountains in the northern Carpathians, Romania. Photography by A. Hofgaard to increased competition among vascular plants and bryophytes (Roth et al. 2013). Increased nutrient availability in the soil, either through artificial fertilization or increased decomposition, will change the species composition. In particular, the cover and frequency of lichen and bryophyte species are reduced, while graminoids and some deciduous shrubs are generally favored (Klanderud 2008, Olsen \& Klanderud 2014). This change in species composition most often results in reduced biodiversity.

Reforestation of husbandry-related grazing lands and other tree colonization in alpine areas requires viable seed production and dispersal from the forest at lower elevation. However, although viable seeds are generally available and easily dispersed by wind

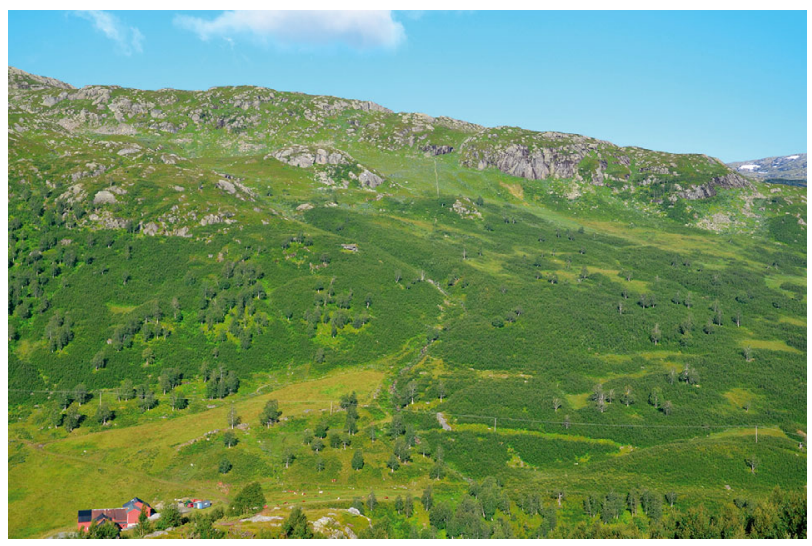

Fig. 6. Re-growth of young birch Betula pubescens after abandoned summer grazing practice. The previously open meadows with scattered old birch is now dominated by a dense layer of birch saplings (dark green). Røldal, southern Norway. Photography by N. Eide

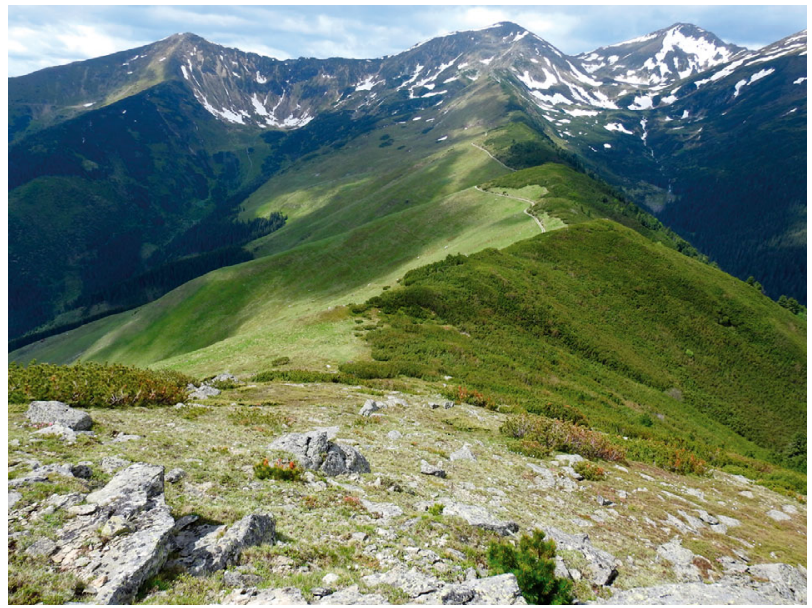

Fig. 7. Mountain pine Pinus mugo quickly colonize abandoned herding areas (right hand side of the ridge) and form a dense shrub cover. In areas with continued herding (left side), the alpine flora prevail. Rodnei Mountains in the northern Carpathians, Romania. Photography by A. Hofgaard 
or birds across the treeline ecotone and beyond, this might not necessarily result in recruitment of tree seedlings surviving to sapling and tree size (Aune et al. 2011). Temporal and transitory seedling cohorts are often characteristic of the upper part of the treeline ecotone (Juntunen et al. 2002, Kullman 2002, Aune et al. 2011) making the tree species line (cf. Fig. 1) very dynamic. Survival and growth to sapling and tree size in the open exposed alpine area requires long-term favorable site conditions with regard to a large number of abiotic and biotic factors, such as topography, snow cover and duration, soil, wind, temperature, moisture, plant density, and herbivory, and the interplay between these factors (Cairns \& Moen 2004, Holtmeier \& Broll 2005, Batllori et al. 2010, Hofgaard et al. 2010). In addition, the importance of these factors is species-specific and varies through time (Holtmeier \& Broll 2005, Hofgaard et al. 2012, Wielgolaski \& Inouye 2013), and the response is also sensitive to the current ecotone structure (Camarero et al. 2017). Consequently, disentangling the causes and predicting treeline ecotone responses to environmental changes are challenging (Sveinbjörnsson et al. 2002), although the most common determinants for treeline ecotone location are temperature and land use (see Section 1.1. above).

Tree advance is initially associated with a change in height growth of previously established saplings (Kullman 2002, Hofgaard et al. 2009) causing densification of the current scattered tree layer (Batllori \& Gutiérrez 2008, Mathisen et al. 2014) and movement of the treeline location (Kullman \& Öberg 2009). Further densification and relocation is dependent on new establishment and survival in the ecotone and beyond the current upper sapling cohort (Kullman 2002, Hofgaard et al. 2009). The increased abundance of trees and tree saplings changes the structure of the ecotone, including enhanced snow trapping during winter, and thus further promotes tree growth and establishment through, for example, reducing wind destruction of leading shoots. During the winter season, soil temperatures under a deep snowpack do not drop much below zero. Soil moisture is increased in the early growing season by the meltwater (Sveinbjörnsson et al. 2002, Dalen \& Hofgaard 2005, Holtmeier 2009).

As trees and forest advance to higher altitudes and latitudes, increasingly more of the former low-alpine or low-arctic area disappears, leaving less space for tundra species (Dirnböck et al. 2003, Gottfried et al. 2012). Knowledge of the rate of this process is important for predictions of tundra disappearance and associated threats to alpine biodiversity and climate feedbacks (Callaghan et al. 2002b, Pearson et al. 2013). Expansion of forest or shrub cover to areas beyond the current forest at high elevation and high latitude has contrasting climate feedbacks through carbon sequestration (cooling) and reduced surface reflectance (warming) (Bala et al. 2007, Pearson et al. 2013, te Beest et al. 2016). According to estimates for Scandinavian mountain forests, the warming effect is considerably stronger than the cooling, because of the typically low density in mountain forests and the large changes in surface reflectance of snow-covered tundra areas (de Wit et al. 2014). However, the change in reflectance caused by vegetation is a slow process, as the rate of forest migration is low due to the multitude of interacting and counteracting abiotic and biotic environmental factors. The typical advance rate for the warming periods since the late 19th century has been less than $1 \mathrm{~m} \mathrm{yr}^{-1}$ altitudinally (Kullman \& Öberg 2009, Kharuk et al. 2010, Mathisen et al. 2014, Cudlín et al. 2017) and some 10s m $\mathrm{yr}^{-1}$ latitudinally (Hofgaard et al. 2013). These empirically based rate estimates represents less than onetenth of model-based rate estimates (Hofgaard et al. 2013), and it is essential to consider this mismatch when discussing magnitude and time frame of potential threats to alpine biodiversity.

\section{ANIMAL IMPACT IN TREELINE AREAS}

In addition to domestic animals, wild fauna depend on, interact with, and change the structure and location of the treeline ecotone. This fauna represents a large number of species of mammals, birds, insects, and other vertebrates and invertebrates. Herbivore activities will have a direct impact through both consumption of biomass (browsing, grazing, seed feeding) and other regular or life history related activities such as trampling, digging, gnawing, and girdling. Animal activities also have indirect impact in treeline areas through e.g. carnivore-herbivore interactions and subsequent animal population dynamics (Hambäck et al. 2004), and through decomposition of dead organic matter by soil-dwelling invertebrates. Quantification of animal impact in treeline areas is not straightforward due to the structural heterogeneity of the ecotone and biogeographic differences throughout Europe. The heterogeneity provides diverse macro- and microhabitats supporting a variety of organisms from soil microorganisms that specialize in particular habitats to animals with large ranges that require different habitats for forage and shelter. 
Further, animals typically associated with forested areas, such as some corvids, deer, wolverine, and red fox, frequently use treeline areas and the above tundra to search for food and occasionally for breeding. Animals associated with tundra, such as lemmings and reindeer, periodically or annually forage in the ecotone (Fig. 8) (Post et al. 2009, Killengreen et al. 2012). In addition, as discussed in Section 2, the structure and quality of present treeline ecotone habitats have often been, and still are, strongly influenced by human activities. As the type and extent of human influences vary regionally and locally, the possibility of generalization is limited. In the following paragraphs, we outline some examples of animal impact in treeline areas.

In the central European mountains, increased numbers of ungulates such as red deer Cervus elaphus have locally suppressed tree regeneration and impaired self-maintenance of tree stands in treeline areas (Loison et al. 2003, Kiffner et al. 2008, Holtmeier 2012). Similarly, but to a lesser extent, chamois Rupicapra rupicapra and ibex Capra ibex herbivory affect saplings and trees across the ecotone (ten Houte de Lange 1978, Senn 2000). In addition, high ungulate densities may cause severe soil erosion both in the treeline ecotone and in the adjacent alpine tundra (Holtmeier 1967, 2012, 2015). In most cases, habitat fragmentation and inadequate game management are major causes of 'over-sized' ungulate populations.

In the north, reindeer (semi-domesticated and wild) occur regionally in large populations, and throughout history, have profoundly affected the vegetation in their foraging range, including the treeline ecotone vegetation (Oksanen et al. 1995, Kashulina et al. 1997, Mårell et al. 2002, Colpaert et al. 2003, Helle \& Kojola 2006, Olofsson et al. 2009). Reindeer grazing may inhibit tree seedling survival and prevent vegetative regeneration from basal shoots of mountain birch (Kaitaniemi et al. 1999, Holtmeier 2002, Cairns \& Moen 2004, Neuvonen \& Wielgolaski 2005, Solberg et al. 2005), and under high reindeer densities, the grazing areas might become increasingly degraded with regard to species diversity and productivity (Kullman 2005, Holtmeier \& Broll 2006, Broll et al. 2007, Käyhkö 2007, Anschlag et al. 2008, Tømmervik et al. 2009). This is particularly evident in winter grazing areas where the main food for reindeer is slow-growing reindeer lichens (Gaare \& Skogland 1975). Lichen ground cover has been strongly reduced both by high grazing pressure and by climate change. In addition to reindeer, increasing north Scandinavian populations

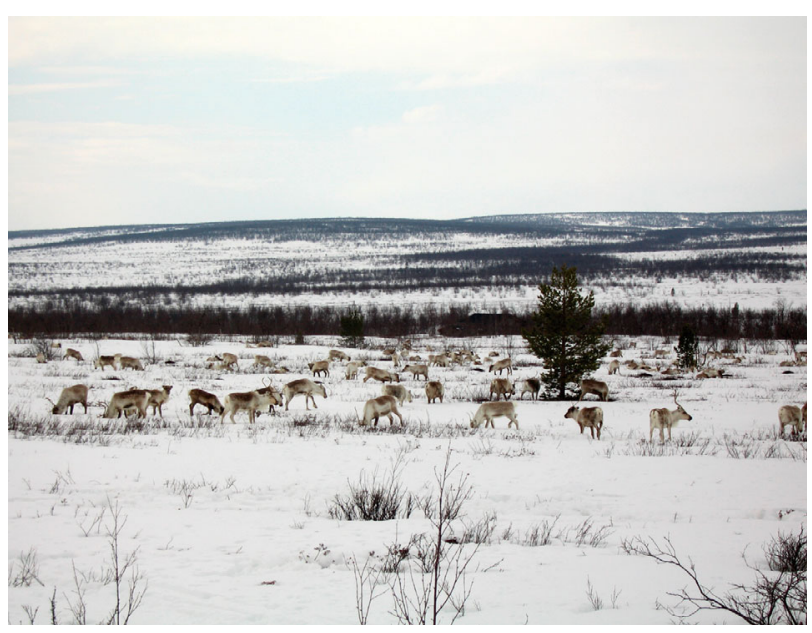

Fig. 8. Winter grazing by semi-domestic reindeer in the treeline ecotone of northern Fennoscandia. Photography by K. Laine

of moose Alces alces are affecting height growth and survival of young Scots pine in treeline areas (Stöcklin \& Körner 1999, Holtmeier \& Broll 2011) and in afforestation areas at lower elevation. These impacts by reindeer and moose on tree recruitment may locally or regionally overrule the influence of changing climate (Stöcklin \& Körner 1999, Aune et al. 2011, Holtmeier 2012), and in the case of reindeer, the carrying capacity of the landscape has sometimes been questioned (Neuvonen \& Wielgolaski 2005, Solberg et al. 2005).

In addition to large mammals, rodents, chiefly microtine rodents, may have a large impact on treeline ecotone vegetation, particularly in north European mountains. In this region, massive population peaks of lemmings Lemmus lemmus and voles, e.g. Microtus agrestis, are well-known biotic characteristics with a return cycle of approximately 4 yr (Andersson \& Jonasson 1986, Henttonen \& Wallgren 2001, Ims \& Fuglei 2005). The grazing and gnawing during population peak periods reduce moss and dwarf shrub cover locally and over large regions (Olofsson et al. 2012, Kaarlejärvi et al. 2015). This fragmentation of the bottom and field layer might facilitate establishment of new mountain birch seedlings. However, lemmings and voles also damage and feed on birch seedlings, and in general, rodents adversely affect young trees and shrubs (Fig. 9) rather than promoting successful seedling establishment. Thus, field vole feeding may hasten birch decline, in combination with outbreaks of defoliating geometrid moths and subsequent reindeer grazing (see below). Further, but not of large scale 

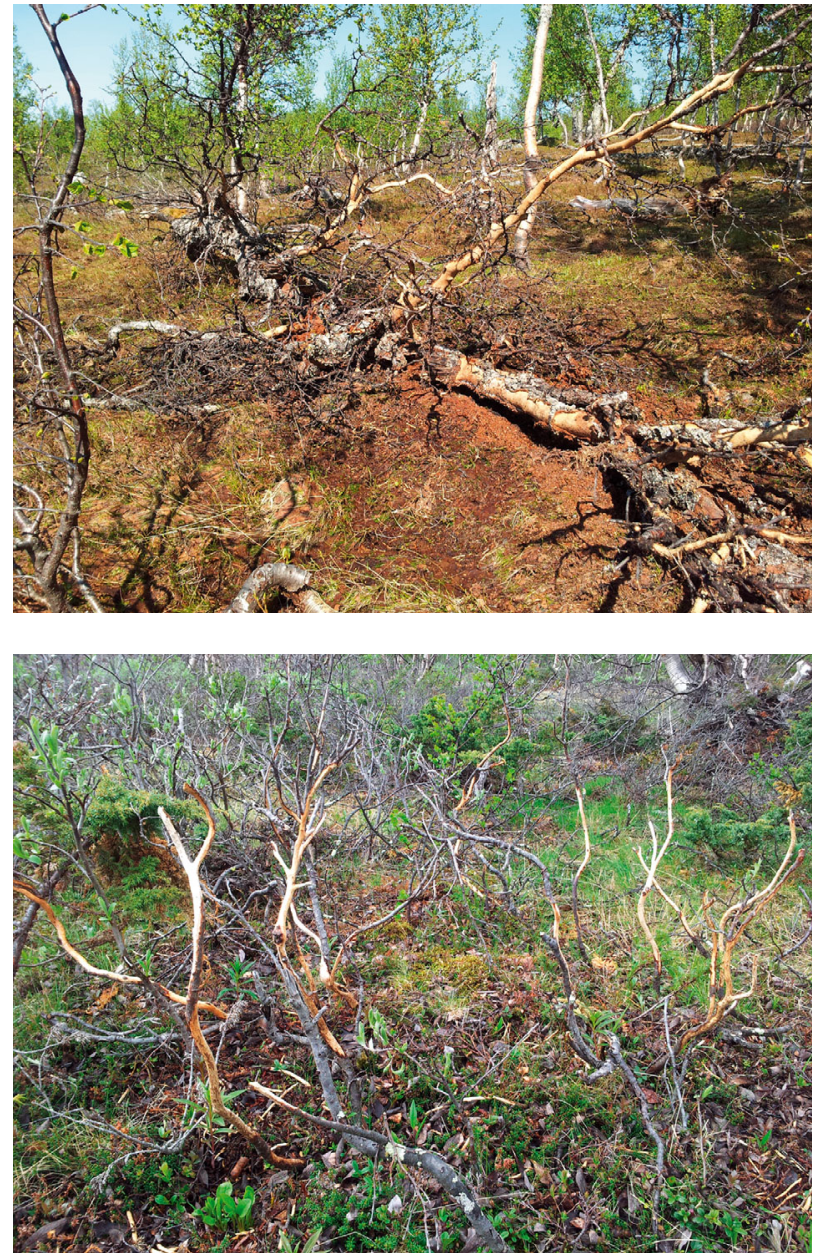

Fig. 9. Lemming and microtine vole forage damage of mountain birch and surrounding woody plants (upper panel) and willow shrubs (Salix sp.) (lower panel). The gnawing activity occurred in winter below the snow surface. Upper panel: Tärnafjällen in the Central Scandes Mountains, Sweden. Lower panel: Abisko in the Northern Scandes Mountains, Sweden. Photography by A. Hofgaard

importance, mountain hares Lepus timidus reduce growth of mountain birch saplings by heavy browsing and damage trees by gnawing off the bark (Rao et al. 2003, Holtmeier 2012).

In northern mountain birch-dominated ecotones and adjacent forest areas, the natural dynamics are driven by cyclic and abrupt population increases of defoliating insects such as the autumnal moth Epirrita autumnata and winter moth Operoptera brumata (Tenow 1972, Tenow et al. 2007). The frequency and intensity of these insect outbreaks are linked to the climate at local to regional scales. They can cause large scale stand mortality and former forest might be turned into tundra (Tenow \& Nilssen 1990, Neuvonen et al. 2005, Tenow et al. 2007). This tundra produced by defoliators, together with the lowered treeline ecotone, might become a long-term state due to intensified reindeer grazing in the newly deforested areas (Kallio \& Lehtonen 1975, Oksanen et al. 1995, Holtmeier et al. 2003, Lempa et al. 2005, Neuvonen \& Wielgolaski 2005, Neuvonen et al. 2005, Holtmeier \& Broll 2006). In a warming climate, expansion of the outbreak range of defoliating insects is likely (Jepsen et al. 2011), and will include higher altitudes and latitudes (Skre et al. 2017, this Special). This might hinder or counteract climate-driven advance of treeline ecotones (Olofsson et al. 2009, Aune et al. 2011, Hofgaard et al. 2013). A parallel to the autumnal moth outbreaks in northern Europe are the cyclic outbreaks of the larch-bud moth Zeiraphera diniana in the European Alps. However, larch stands at treeline ecotone elevations are generally not affected due to the low density of trees. At lower elevations, increased cyclic outbreaks are probably due to human-induced expansion of pure larch forests. In cases of severe defoliation, growth and seed production are reduced (Holtmeier 1974, 2015).

Soil-dwelling invertebrates (e.g. earthworms, enchytraeids, collembola, spiders, tardigrades, woodlice, snails, millipedes, nematodes, dipteral larvae, and ants) play an important role through breaking down dead organic matter, mineral-rich (nitrogen, phosphorous) excretory products, and bioturbation, thus influencing nutrient turnover and plant communities (Broll 1998, Holtmeier 2015). In general, taxa, abundance, biomass, and species richness of soildwelling invertebrates decrease with altitude. In the treeline ecotone, however, they are controlled by often sharply contrasting site conditions (geological substrate, soils, microclimates, moisture, vegetation) overlapping with historical human impact (Holtmeier 2009). However, in contrast to mass outbreaks of leafeating insects, soil invertebrates do not significantly influence treeline spatial and temporal structures, whereas reforestation of abandoned alpine pastures will probably bring about major changes influencing soil invertebrate fauna and also aboveground insects and ground beetles (Carabidae) in the long-term. Predicting possible feedbacks on the treeline, however, is difficult because of the often inscrutable interactions of the numerous environmental factors and their relative implications (Holtmeier 2009, 2015).

Among birds, the Eurasian nutcracker Nucifraga caryocatactes is a highly effective agent influencing the tree distribution pattern of stone pine Pinus cembra and the dynamics of treeline ecotones in central and eastern European mountain areas due to its 
seed-caching activities (Zong et al. 2010, Holtmeier 2012, 2015). Surplus stored seeds (i.e. seeds not consumed during the winter) may germinate and result in the establishment of trees in new areas and at higher elevation. This bird-mediated sowing has contributed to the re-establishment of stone pine over large areas formerly cleared by man. Further, without the nutcracker, natural upward advancement of trees in response to climatic warming would be impossible. Birds other than nutcrackers, e.g. grouse and ptarmigan species, and seed-eating birds, usually have a low impact on the treeline ecotone. However, grouse and ptarmigan species might locally limit growth, particularly of young trees, by consuming or destroying buds and terminal shoots (Holtmeier 2012, 2015), and in addition, pastoral abandonment may lead to an overall increase in avian diversity (Laiolo et al. 2004) due to increased shrub and tree cover.

\section{CASCADING EFFECTS OF LAND USE AND CLIMATE CHANGES: A SCENARIO EXAMPLE FROM THE NORTH}

The outcome of combined pressure on the natural environment by intense land use and climate changes might be difficult to quantitatively and qualitatively forecast. However, it is necessary to consider the matter for sustainable management reasons. A commonly discussed example is the semi-domestic reindeer herding system in northern Scandinavia. The long history of the herding system has shaped the distribution and abundance of species and thus formed the current cultural landscape. However, the herding system is not static and has to adapt to modern socioeconomic changes and requirements, at the same time as the climate is both highly variable and changing. Here we outline some of the biological complexities involved (see also Sections $2 \& 3$ above). While reindeer owners may wish to increase their income by allowing more animals within a given area, this of course will result in increased grazing pressure. The new grazing regime might or might not initially affect both summer (herb-dominated) and winter (lichen-dominated) grazing grounds, but winter areas are common bottlenecks in the annual migration practice. Lichens are a major reindeer food source in the winter, and accessibility varies widely between individual winters due to snow quality. Warm winters with rain and icing events force reindeer to use a lot of energy digging for lichens. Due to the very slow growth rate of lichens, considerable

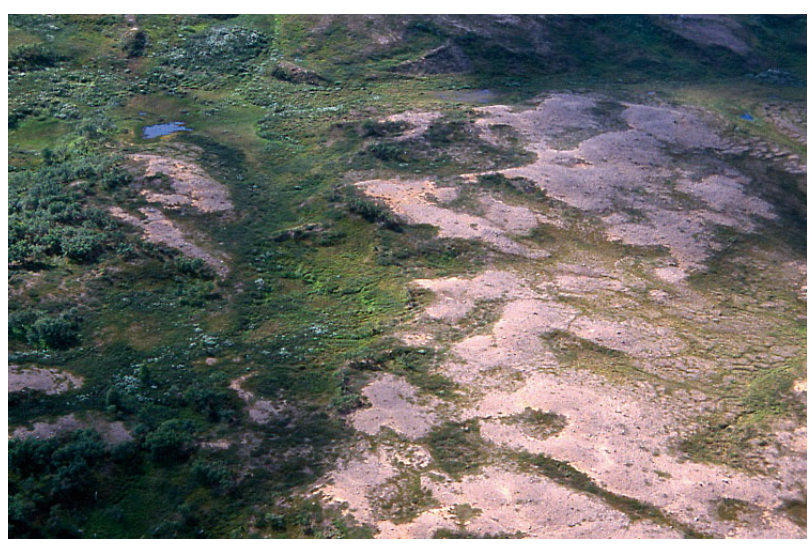

Fig. 10. Wind-eroded convex topography on Koahppeloaivi (northernmost Finnish Lapland). The substrate is rapidly draining sandy-skeletal glacial till. Erosion was initiated by reindeer winter-grazing activities that destroyed the dwarf shrub-lichen vegetation and made the substrate susceptible to deflation. Moisture deficiency is characteristic of such sites and adversely affects tree seedling establishment. The photograph was taken from approximately 250 to $300 \mathrm{~m}$ above ground. Photography by F. K. Holtmeier

time is needed for vegetation recovery following excess removal of lichens by e.g. too high grazing pressure. At the same time, digging for lichens by the reindeer population cause patches of open soil, which facilitate establishment of higher plants, e.g. mountain birch. Birch is further facilitated by the ongoing increased temperature and precipitation in the region, although on well drained substrates exposed by reindeer scraping and trampling, moisture deficiency affects or prevents birch seedling establishment (Fig. 10). Increased temperature and moisture availability may also increase decomposition rate and mineralization of organic material. In these ways, nutrient-demanding plant species may outcompete the slow-growing lichens. Because of diminishing lichen cover, the reindeer population has to adjust its diet to include vascular plant parts such as the young shoots of birch saplings. However, at increased temperatures in winter, the survival rate of the eggs of defoliating insects using birch as host species will increase along with arrival of new defoliating species in the area. Increased frequency of defoliators and increased spatiotemporal outbreak occurrence may transform birch-dominated areas to treeless tundra. The quality of these areas as winter grazing areas is thus further diminished, and the reindeer owners will have to reduce the number of animals using the area or keep the herds in summer grazing areas for prolonged periods. This will, however, cause other cascading effects. 


\section{CONCLUDING REMARKS AND PERSPECTIVES}

While from a continent-wide view, thermal deficiency increasing with elevation and latitude controls treeline ecotone structure and position, many other climatic and biotic factors are involved at regional and smaller scales. Not least, the after effects of historical human impact are often of major importance and may overrule the influence of natural factors. Therefore, assessment of treeline ecotone variety and causation needs a cross-disciplinary complex approach combining natural and socio-economic sciences. Climate change, reduced pastoral use, and increased tourism and other human uses are the main driving factors of current changes across the treeline ecotone. The role of animals (wild and domestic or semi-domestic ungulates, rodents, birds, and insects) in the treeline ecotone needs to be studied in more detail, in particular regarding possible cascading effects such as the presented mountain birch-reindeer scenario. Treeline ecotone change will have farreaching implications for biodiversity, plant and animal communities, and also for the relative effects of microtopography on site conditions (microclimates, soil ecological conditions) and ecosystem services (e.g. protection from destructive avalanches, prevention/reduction of soil erosion).

Acknowledgements. This article is based on work from COST Action ES 1203 (SENSFOR), supported by COST (European Cooperation in Science and Technology), www. cost.eu. We are in addition thankful for financial support from the CLIMFOR project (grant code EEA-jrp-ro-no-20131-0204), the Research Council of Norway (grant nos. 160022/F40 and 244557/E50), the German Research Foundation, and the Lapland Atmosphere-Biosphere Facility (LAPBIAT, EU)

\section{LITERATURE CITED}

Aas B, Faarlund T (1996) The present and the Holocene subalpine birch belt in Norway. In: Frenzel B, Birks $\mathrm{HH}$, Alm T, Vorren KD (eds) Holocene treeline oscilllations, dendrochronology and palaeoclimate. Paläoklimaforschung - Palaeoclimate Res, Vol 20. Gustav Fischer, Stuttgart, p 19-42

Aas B, Faarlund T (2001) The Holocene history of the Nordic maintain birch belt. In: Wielgolaski FE (ed) Nordic mountain birch ecosystems. Man and the Biosphere Series 27. Parthenon Publishing-UNESCO, Paris, London, New York, p 5-22

Alexander JM, Diez JM, Levine JM (2015) Novel competitors shape species' responses to climate change. Nature 525:515-518

Allen JRM, Huntley B (1999) Estimating past floristic diver- sity in montane regions from macrofossil assemblages. J Biogeogr 26:55-73

Ameztegui A, Brotons L, Coll L (2010) Land-use changes as major drivers of mountain pine (Pinus uncinata Ram.) expansion in the Pyrenees. Glob Ecol Biogeogr 19:632-641

Andersson JM, Jonasson S (1986) Rodent cycles in relation to food resources on an alpine heath. Oikos 46:93-106

* Anschlag K, Broll G, Holtmeier FK (2008) Mountain birch seedlings in the treeline ecotone, Subarctic Finland. Variation in above- and below-ground growth in relation to microtopography. Arct Antarct Alp Res 40:609-616

* Aune S, Hofgaard A, Söderström L (2011) Contrasting climate and land use driven tree encroachment pattern of sub-arctic tundra in Northern Norway and Kola Peninsula. Can J For Res 41:437-449

Austrheim G, Mysterud A, Pedersen B, Halvorsen R, Hassel K, Evju M (2008) Large scale experimental effects of three levels of sheep densities on an alpine ecosystem. Oikos 117:837-846

Bala G, Caldeira K, Wickett M, Phillips TJ, Lobell DB, Delire C, Mirin A (2007) Combined climate and carbon-cycle effects of large-scale deforestation. Proc Natl Acad Sci USA 104:6550-6555

Batllori E, Gutiérrez E (2008) Regional tree line dynamics in response to global change in the Pyrenees. J Ecol 96: 1275-1288

Batllori E, Camarero JJ, Gutiérrez E (2010) Current regeneration patterns at the tree line in the Pyrenees indicate similar recruitment processes irrespective of the past disturbance regime. J Biogeogr 37:1938-1950

Bolli JC, Rigling A, Bugmann H (2007) The influence of changes in climate and land-use on regeneration dynamics of Norway spruce at the treeline in the Swiss Alps. Silva Fenn 41:55-70

Brandes R, Ise M (2007) Fingerprints of climate change in Mediterranean mountain forests? Observations in Mediterranean fir-species threatened by climate change. Geo-Öko 28:1-26

Brockmann-Jerosch H (1919) Baumgrenze und Klimacharakter. Beiträge zur geobotanischen Landesaufnahme 6, Zürich

Broll G (1998) Diversity of soil organisms in alpine and arctic soils in Europe. Review and research needs. Pireneos 151-152:43-72

Broll G, Holtmeier FK, Anschlag K, Brauckmann HJ, Wald S, Drees B (2007) Landscape mosaic in the treeline ecotone on Mt. Rodjanoaivi, subarctic Finland. Fennia 185:89-105

Bryn A (2008) Recent forest limit changes in south-east Norway: effects of climate change or regrowth after abandoned utilisation? Nor Geogr Tidsskr 62:251-270

Bryn A, Daugstad K (2001) Summer farming in the subalpine birch forest. In: Wielgolaski FE (ed) Nordic mountain birch ecosystems. Man and the Biosphere Series 27. Parthenon Publishing-UNESCO, Paris, London, New York, p 307-315

Bryn A, Hemsing LO (2012) Impacts of land use on the vegetation in three rural landscapes of Norway. Int $\mathrm{J}$ Biodivers Sci Ecosyst Serv Manag 8:360-371

* Bryn A, Dourojeanni P, Hemsing LO, O'Donnell S (2013) A high-resolution GIS null model of potential forest expansion following land use changes in Norway. Scand J For Res 28:81-98

* Bühlmann T, Körner C, Hiltbrunner E (2016) Shrub expansion of Alnus viridis drives former montane grassland into nitrogen saturation. Ecosystems 19:968-985 
Cairns D, Moen J (2004) Herbivory influences tree lines. J Ecol 92:1019-1024

Callaghan TV, Werkman BR, Crawford RMM (2002a) The tundra-taiga interface and its dynamics: concepts and applications. Ambio Spec Rep 12:6-14

Callaghan TV, Crawford RMM, Eronen M, Hofgaard A and others (2002b) The dynamics of the tundra taiga boundary: an overview and a co-ordinated and integrated approach to research. Ambio Spec Rep 12:3-5

Callaghan TV, Björn LO, Chernov Y, Chapin T and others (2004) Biodiversity, distributions and adaptations of Arctic species in the context of environmental change. Ambio 33:404-417

Callaghan TV, Jonasson C, Thierfelder T, Yang Z and others (2013) Ecosystem change and stability over multiple decades in the Swedish subarctic: complex processes and multiple drivers. Phil Trans R Soc B 368:20120488

Camarero JJ, Gutiérrez E (2004) Pace and pattern of recent treeline dynamics: response of ecotones to climatic variability in the Spanish Pyrenees. Clim Change 63: $181-200$

* Camarero JJ, Gutiérrez E (2007) Response of Pinus uncinata recruitment to climate warming and changes in grazing pressure in an isolated population of the Iberian system (NE Spain). Arct Antarct Alp Res 39:210-217

Camarero JJ, Linares JC, García-Cervigón AI, Batllori E, Martínez I, Gutiérrez E (2017) Back to the future: the responses of alpine treelines to climate warming are constrained by the current ecotone structure. Ecosystems 20: $683-700$

Cardinale BJ, Duffy JE, Gonzales A, Hooper DU and others (2012) Biodiversity loss and its impact on humanity. Nature 486:59-67

Chauchard S, Carcaillet C, Guibal F (2007) Patterns of landuse abandonment control tree-recruitment and forest dynamics in Mediterranean mountains. Ecosystems 10: 936-948

Colpaert A, Kumpula J, Nieminen M (2003) Reindeer pasture biomass assessment using satellite remote sensing. Arctic 56:147-158

Crooks JA, Soulé ME (1999) Lag times in population explosions of invasive species: causes and implications. In: Sandlund OT, Schei PJ, Viken $\AA$ (eds) Invasive species and biodiversity management. Kluwer, Dordrecht, p 103-125

Cudlín P, Klopčič M, Tognetti R, Malis F and others (2017) Drivers of treeline shift in different European mountains. Clim Res 73:135-150

Dalen L, Hofgaard A (2005) Differential regional treeline dynamics in the Scandes Mountains. Arct Antarct Alp Res 37:284-296

De Quervain A (1904) Die Hebung der atmosphärischen Isothermen in den Schweizer Alpen und ihre Beziehung zu den Höhengrenzen. Gerlands Beitr Geophys 6:481-533

* de Wit HA, Bryn A, Hofgaard A, Karstensen J, Kvalevåg M, Peters G (2014) Climate warming feedback from mountain birch forest expansion: reduced albedo dominates carbon uptake. Glob Chang Biol 20:2344-2355

Dinca L, Nita MD, Hofgaard A, Alados CL and others (2017) Forests dynamics in the montane-alpine boundary: a comparative study using satellite imagery and climate data. Clim Res 73:97-110

* Dirnböck T, Dullinger S, Grabherr G (2003) A regional impact assessment of climate and land-use change on alpine vegetation. J Biogeogr 30:401-417
Emanuelsson U (1987) Human influence on vegetation in the Torneträsk area during the last three centuries. Ecol Bull 38:95-111

Fischer M, Rudmann-Maurer K, Weyand A, Stöcklin J (2008) Agricultural land use and biodiversity in the Alps. Mt Res Dev 28:148-155

Fleischer P, Pichler V, Fleischer P Jr, Holko L and others (2017) Forest ecosystem services affected by natural disturbances, climate and land-use changes in the Tatra Mountains. Clim Res 73:57-71

Forbes BC, Tolvanen A, Wielgolaski FE, Laine K (2005) Rates and processes of natural regeneration in disturbed habitats. In: Wielgolaski FE (ed) Plant ecology, herbivory, and human impact in Nordic mountain birch forests. Ecological Studies 180. Springer-Verlag, Berlin, p 193-202

Gaare E, Skogland T (1975) Wild reindeer food habits and range use at Hardangervidda. In: Wielgolaski FE (ed) Fennoscandian tundra ecosystems, Part 2, Animals and systems analysis. Ecological Studies 17. Springer-Verlag, Berlin, p 195-205

KGarcia-Ruiz J, Lasanta T, Ruiz-Flano P, Ortigosa L, White S, González C, Martí C (1996) Land-use changes and sustainable development in mountain areas: a case study in the Spanish Pyrenees. Landsc Ecol 11:267-277

Gehrig-Fasel J, Gusian A, Zimmermann N (2007) Tree line shifts in the Swiss Alps: Climate change or land abandonment? J Veg Sci 18:571-582

*Gervais BR, MacDonald GM (2000) A 403-year record of July temperatures and treeline dynamics of Pinus sylvestris from the Kola Peninsula, Northwest Russia. Arct Antarct Alp Res 32:295-302

Gonzáles de Andrés E, Camarero JJ, Büntgen U (2015) Complex climate constraints of upper treeline formation in the Pyrenees. Trees 29:941-952

KGottfried M, Pauli H, Futschik A, Akhalkatsi M and others (2012) Continent-wide response of mountain vegetation to climate change. Nat Clim Chang 2:111-115

Grove JM (1988) The Little Ice Age. Methuen, London

Grunewald K, Scheithauer J (2008) Untersuchungen an der alpinen Waldgrenze im Piringebirge (Bulgarien). GeoÖko 29:1-32

Grytnes JA, Kapfer J, Jurasinski G, Birks HH and others (2014) Identifying the driving factors behind observed elevational range shifts on European mountains. Glob Ecol Biogeogr 23:876-884

КHambäck PA, Oksanen L, Ekerholm P, Lindgren A, Oksanen T, Schneideret M (2004) Predators indirectly protect tundra plants by reducing herbivore abundance. Oikos 106:85-92

Hanssen-Bauer I, Førland EJ, Haddeland I, Hisdal H and others (2015) Klima i Norge 2100. Kunnskapsgrunnlag for klimatilpasning oppdatert 2015. Norsk klimaservicesenter rapport, no. 2/2015

Harsch MA, Hulme PE, McGlone M, Duncan RP (2009) Are treelines advancing? A global meta-analysis of treeline response to climate warming. Ecol Lett 12:1040-1049

Heiri C, Bugmann H, Tinner W, Heiri O, Lischke H (2006) A model-based reconstruction of Holocene treeline dynamics in the Central Swis Alps. J Ecol 94:206-216

Helle T, Kojola I (2006) Population trends of semi-domesticated reindeer in Fennoscandia-evaluation of explanations. In: Forbes BC, Bölter M, Müller-Wille L, Hukkinen J, Müller F, Gunslay N, Konstantino Y (eds) Reindeer management in northernmost Europe: Linking 
practical and scientific knowledge in socio-ecological systems. Ecological Studies 148. Springer-Verlag, Berlin, p 319-339

Henttonen H, Wallgren H (2001) Rodent dynamics and communities in the birch forest zone of northern Fennoscandia. In: Wielgolaski FE (ed) Nordic mountain birch ecosystems. Man and the Biosphere Series 27 , Parthenon Publishing-UNESCO, Paris, p 261-278

Hofgaard A (1997a) Structural changes in the forest-tundra ecotone: a dynamic process. In: Huntley B, Cramer W, Morgan AV, Prentice HC, Allen JRM (eds) Past and future rapid environmental changes: the spatial and evolutionary responses of terrestrial biota. NATO ASI Series, Vol I 47, Springer-Verlag, Berlin, p 255-263

*Hofgaard A (1997b) Inter-relationships between treeline position, species diversity, land-use and climate change, in the central Scandes Mountains of Norway. Glob Ecol Biogeogr Lett 6:419-429

Hofgaard A (1999) The role of 'natural' landscapes influenced by man in predicting responses to climate change. Ecol Bull 47:160-167

* Hofgaard A, Wilmann B (2002) Plant distribution patterns across the forest-tundra ecotone. The importance of treeline position. Ecoscience 9:375-385

* Hofgaard A, Dalen L, Hytteborn H (2009) Tree recruitment above the treeline and potential for climate driven treeline change. J Veg Sci 20:1133-1144

Hofgaard A, Løkken JO, Dalen L, Hytteborn H (2010) Comparing warming and grazing effects on birch growth in an alpine environment - a 10 year experiment. Plant Ecol Divers 3:19-27

Hofgaard A, Harper KA, Golubeva E (2012) The role of the circumarctic forest-tundra ecotone for arctic biodiversity. Biodiversity (Nepean) 13:174-181

* Hofgaard A, Tømmervik H, Rees G, Hanssen F (2013) Latitudinal forest advance in northernmost Norway since the early 20th century. J Biogeogr 40:938-949

Holtmeier FK (1967) Das Steinwild in der Landschaft von Pontresina. Natur Mus 99:15-24

Holtmeier FK (1974) Geoökologische Beobachtungen und Studien an der subarktischen und alpinen Waldgrenze in vergleichender Sicht (nördliches Fennoskandie/Zentralalpen). Erdwissenschaftliche Forschung 8. Franz Steiner Verlag, Wiesbaden

Holtmeier FK (1981) What does the term 'krummholz' really mean? Observations with special reference to the Alps and the Colorado Front Range. Mt Res Dev 1:253-260

Holtmeier FK (1987) Human impacts in high altitude forests and upper timberline with special reference to middle latitudes. In: Fujimori T, Kimura M (eds) Human impacts and management of mountain forests. Forest Products Research Institute, Ibaraki, p 9-20

Holtmeier FK (1993) Timber lines as indicators of climatic changes: problems and research needs. In: Frenzel B (ed) Oscillations of the alpine and polar tree limits in the Holocene. Paläoklimaforschung - Palaeoclimate Res, Vol 9. Gustav Fischer, Stuttgart, p 211-222

Holtmeier FK (2002) Tiere in der Landschaft. Einfluß und ökologische Bedeutung. Ulmer, Stuttgart

Holtmeier FK (2009) Mountain timberlines. Ecology, patchiness, and dynamics. Advances in Global Change Research 36. Springer, Dordrecht

Holtmeier FK (2012) Impact of wild herbivorous mammals and birds on the altitudinal and northern treeline ecotones. Landsc Online 30:1-28
Holtmeier FK (2015) Animals' influence on the landscape and ecological importance. Natives, newcomers, homecomers. Springer, Dordrecht

Holtmeier FK, Broll G (2005) Sensitivity and response of northern hemisphere altitudinal and polar treelines to environmental change at landscape and local scales. Glob Ecol Biogeogr 14:395-410

*Holtmeier FK, Broll G (2006) Radiocarbon-dated peat and wood remains from the Finnish Subarctic: evidence of treeline and landscape history. Holocene 16:743-751

Holtmeier FK, Broll G (2010) Altitudinal and polar treelines in the northern hemisphere - causes and response to climate change. Polarforschung 79:139-153

* Holtmeier FK, Broll G (2011) Response of Scots pine (Pinus sylvestris) to warming climate at its altitudinal limit in northernmost subarctic Finland. Arctic 64:269-280

Holtmeier FK, Broll G (2012) Landform influences on treeline patchiness and dynamics in a changing climate. Phys Geogr 35:430-437

*Holtmeier FK, Broll G (2017) Feedback effects of clonal groups and tree clusters on site conditions at the treeline: implications for treeline dynamics. Clim Res 73:85-96

Holtmeier FK, Broll G, Müterthies A, Anschlag K (2003) Regenertaion of trees in the treeline ecotone: northern Finnish Lapland. Fennia 181:103-128

Huston MA (1994) Biological diversity: the coexistence of species on a changing landscape. Cambridge University Press, Cambridge

Ims RA, Fuglei E (2005) Trophic interaction cycles in tundra ecosystems and the impact of climate change. Bioscience 55:311-322

Irl SDH, Anthelme F, Harter DEV, Jentsch A, Lotter E, Steinbauer MJ, Beirkuhnlein C (2016) Patterns of island treeline elevation - a global perspective. Ecography 39: 427-436

Jepsen JU, Kapari L, Hagen SB, Schott T, Vindstad OPL, Nilssen AC, Ims RA (2011) Rapid northwards expansion of a forest insect pest attributed to spring phenology matching with sub-Arctic birch. Glob Change Biol 17: 2071-2083

Juntunen V, Neuvonen S, Norokorpi Y, Tasanen T (2002) Potential for timberline advance in northern Finland, as revealed by monitoring during 1983-99. Arctic 55: 348-361

Kaarlejärvi E, Hoset KS, Olofsson J (2015) Mammalian herbivores confer resilience of Arctic shrub-dominated ecosystems to changing climate. Glob Chang Biol 21: 3379-3388

Kaitaniemi P, Neuvonen S, Nyyssönen T (1999) Effects of cumulative defoliation on growth, reproduction, and insect resistance in the mountain birch. Ecology 80: 524-532

Kallio P, Lehtonen J (1975) On the ecocatastophe of birch forests cause by Oporinia autumnata (BKH) and the problem of reforestation. In: Wielgolaski FE (ed) Fennoscandian tundra ecosystems. 2. Ecological Studies 17. Springer-Verlag, Berlin, p 174-180

Karlén W (1976) Lacustrine sediments and tree-limit variations as indicators of Holocene climatic fluctuations in Lappland: northern Sweden. Geogr Ann 58:1-34

Karlsen SR, Tømmervik H, Johansen B, Riseth JÅ (2017) Future forest distribution on Finnmarksvidda, North Norway. Clim Res 73:125-133

Kashulina G, Reimann C, Finne TE, Halleraker JH, Äyräs M, Chekushin VA (1997) The ecosystem of the central Bar- 
ents Region: scale, factors and mechanisms of disturbance. Sci Total Environ 206:203-225

Kašpar J, Treml V (2016) Thermal characteristics of alpine treelines in Central Europe north of the Alps. Clim Res 68:1-12

Käyhkö J (2007) Aeolian blowout dynamics in subarctic Lapland based on decadal levelling investigations. Geogr Ann 89:65-81

Kharuk VI, Ranson KJ, Im ST, Vdovin AS (2010) Spatial distribution and temporal dynamics of high-elevation forest stands in southern Siberia. Glob Ecol Biogeogr 19: 822-830

Kiffner C, Rössiger E, Trisl O, Schulz R, Rühe F (2008) Probability of recent bark stripping damage by red deer (Cervus elaphus) on Norway spruce (Picea abies) in a low mountain range in Germany - a preliminary analysis. Silva Fenn 42:125-134

Killengreen ST, Strømseng E, Yoccoz NG, Ims RA (2012) How ecological neighbourhoods influence the structure of the scavanger guild in low arctic tundra. Divers Distrib 18:563-574

Klanderud K (2008) Species-specific responses of an alpine plant community under simulated environmental change. J Veg Sci 19:363-372

Körner C (2003) Alpine plant life. Springer-Verlag, Berlin

Körner C (2012) Alpine treelines. Springer, Basel

Kouki J (1999) Latitudinal gradients in species richness in northern areas: some exceptional patterns. Ecol Bull 47: 30-37

Kulakowski D, Barbeito I, Casteller A, Kaczka R, Bebi P (2016) Not only climate: Interacting drivers of treeline change in Europe. Geogr Pol 89:7-15

Kullman L (1986) Recent tree-limit history of Picea abies in the southern Swedish Scandes. Can J Res 16:761-771

* Kullman L (1995) Holocene tree-limit and climate history from the Scandes Mountains, Sweden. Ecology 76: 2490-2502

Kullman L (2002) Rapid recent range-margin rise of tree and shrub species in the Swedish Scandes. J Ecol 90:68-77

Kullman L (2003) Recent reversal of Neoglacial climate cooling trend in the Swedish Scandes as evidenced by mountain birch tree-limit rise. Global Planet Change 36:77-88

Kullman L (2004) Early Holocene appearance of mountain birch (Betula pubescens ssp. tortuosa) at unprecedented high elevations in the Swedish Scandes: megafossil evidence exposed by recent snow and ice recession. Arct Antarct Alp Res 36:172-180

Kullman L (2005) Wind-conditioned $20^{\text {th }}$ century decline of birch treeline vegetation in the Swedish Scandes. Arctic 58:286-294

Kullman L, Källgren L (2000) A coherent postglacial treelimit chronology (Pinus sylvestris L.) for the Swedish Scandes: aspects of paleoclimate and 'recent warming' based on megafossil evidence. Arct Antarct Alp Res 32: $419-428$

Kullman L, Öberg L (2009) Post-Little Ice Age tree line rise and climate warming in the Swedish Scandes: a landscape ecological perspective. J Ecol 97:415-429

Kyriazopoulos AP, Skre O, Sarkki S, Wielgolaski FE, Abraham EM, Ficko A (2017) Human-environment dynamics in European treeline ecosystems: a synthesis based on the DPSIR framework. Clim Res 73:17-29

Laiolo P, Dondero F, Ciliento E, Rolando A (2004) Consequences of pastoral abandonment for the structure and diversity of the alpine avifauna. J Appl Ecol 41:294-304
Lempa K, Neuvonen S, Tømmervik H (2005) Effect of reindeer grazing on pastures. A necessary basis for sustainable reindeer herding. In: Wielgolaski FE (ed) Plant ecology, herbivory, and human impact in Nordic mountain birch forests. Ecological Studies 180. Springer-Verlag, Berlin, p 159-164

Loison A, Toïgo C, Gaillard JM (2003) Large herbivores in European alpine ecosystems: current status and challenges for the future. In: Nagy L, Grabherr G, Körner C, Thompson DBA (eds) Alpine biodiversity in Europe. Ecological Studies 167. Springer-Verlag, Berlin, p 351-366

* Mårell A, Ball JP, Hofgaard A (2002) Foraging and movements paths of female reindeer: insights from fractal analysis, correlated random walks, and Lévy flights. Can J Zool 80:854-865

* Mathisen IE, Mikheeva A, Tutubalina OV, Aune S, Hofgaard A (2014) Fifty years of tree line change in Khibiny Mountains, Russia: advantages of combined remote sensing and dendroecological approaches. Appl Veg Sci $17: 6-16$

Mooney HA, Hofgaard A (1999) Biological invasions and global change. In: Sandlund OT, Schei PJ, Viken Å (eds) Invasive species and biodiversity management. Kluwer, Dordrecht, p 139-148

* Motta R, Morales M, Nola P (2006) Human land-use, forest dynamics and tree growth at the treeline in the Western Italian Alps. Ann Sci 63:739-747

Nagy L, Grabherr G (2009) The biology of alpine habitats. Oxford University Press, New York, NY

Nagy L, Grabherr G, Körner C, Thompson DBA (2003) Alpine biodiversity in space and time: a synthesis. In: Nagy L, Grabherr G, Körner C, Thompson DBA (eds) Alpine biodiversity in Europe. Ecological Studies 167. Springer-Verlag, Berlin, p 453-464

Neuvonen S, Wielgolaski FE (2005) Herbivory in northern birch forests. In: Wielgolaski FE (ed) Plant ecology, herbivory, and human impact in Nordic mountain birch forests. Ecological Studies 180. Springer-Verlag, Berlin, p 183-189

Neuvonen S, Bylund H, Tømmervik H (2005) Forest defoliation risks in birch forest by insects under different climate and land use scenarios in northern Europe. In: Wielgolaski FE (ed) Plant ecology, herbivory, and human impact in Nordic mountain birch forests. Ecological Studies 180. Springer-Verlag, Berlin, p 125-138

Nijnik A, Nijnik M, Kopiy S, Zahvoyska L, Sarkki S, Kopiy L, Miller D (2017) Identifying and understanding attitudinal diversity on multi-functional changes in woodlands of the Ukrainian Carpathians. Clim Res 73:45-56

Oksanen L, Moen J, Helle T (1995) Timberline patterns in northernmost Fennoscandia. Relative importance of climate and grazing. Acta Bot Fenn 153:93-105

* Olofsson J, Oksanen L, Callaghan T, Hulme PE, Oksanen T, Suominen $O$ (2009) Herbivores inhibit climate-driven shrub expansion on the tundra. Glob Chang Biol 15: 2681-2693

\% Olofsson J, Tømmervik H, Callaghan TV (2012) Vole and lemming activity observed from space. Nat Clim Chang 2:880-883

Olsen SL, Klanderud K (2014) Exclusion of herbivores slows down recovery after experimental warming and nutrient addition in an alpine plant community. J Ecol 102: 1129-1137

* Pearson RG, Phillips SJ, Loranty MM, Beck PSA, Damoulas T, Knight SA, Goetz SJ (2013) Shifts in Arctic vegetation 
and associated feedbacks under climate change. Nat Clim Chang 3:673-677

Petitpierre B, McDougall K, Seipel T, Broennimann O, Guisan A, Kueffer C (2016) Will climate change increase risk of plant invasions into mountains? Ecol Appl 26:530-544

Post E, Forchhammer MC, Bret-Harte MS, Callaghan TV and others (2009) Ecological dynamics across the Arctic associated with recent climate change. Science 325: 1355-1358

Rao SK, Iason GR, Hulbert IAR, Elston DA, Pracey PA (2003) The effect of sapling density, heather height and season of browsing by mountain hares on birch. J Ecol 40: 626-638

Rixen C, Rolando A (eds) (2013) The impacts of skiing and related winter recreational activities on mountain environments. Bentham e Books

Rohde K (1992) Latitudinal gradients in species diversity: the search for the primary cause. Oikos 65:514-527

Roth T, Kohli L, Rihm B, Achermann B (2013) Nitrogen deposition is negatively related to species richness and species composition of vascular plants and bryophytes in Swiss mountain grassland. Agric Ecosyst Environ 178: 121-126

Sala OE, Chapin FS III, Armesto JJ, Berlow E and others (2000) Global biodiversity scenarios for the year 2100 . Science 287:1770-1774

* Sarkki S, Ficko A, Grunewald K, Nijnik M (2016) Benefits from and threats to European treeline ecosystem services: an exploratory study of stakeholders and governance. Reg Environ Change 16:2019-2032

Sarkki S, Ficko A, Wielgolaski FE, Abraham EM and others (2017a) Assessing the resilient provision of ecosystem services by social-ecological systems: introduction and theory. Clim Res 73:7-16

Sarkki S, Jokinen M, Nijnik M, Zahvoyska L and others (2017b) Social equity in governance of ecosystem services: synthesis from European treeline areas. Clim Res 73:31-44

Sato CF, Wood JT, Lindenmayer DB (2013) The effects of winter recreation on alpine and subalpine fauna: a systematic review and meta-analysis. PLOS ONE 8:e64282

Schwörer C, Henne PD, Tinner W (2014) A model-data comparison of Holocene timberline changes in the Swiss Alps reveals past and future drivers of mountain forest dynamics. Glob Chang Biol 20:1512-1526

Senn J (2000) Huftiere und Verjüngung im Gebirgswald: eine Geschichte mit vielen Variablen und noch mehr Interaktionen. Schweiz Z Forstwes 151:99-106

Shiyatov SG (1993) The upper timberline dynamics during the last 1100 years in the Polar Ural Mountains. In: Frenzel B (ed) Oscillations of the alpine and polar tree limits in the Holocene. Paläoklimaforschung - Palaeoclimate Res, Vol 9. Gustav Fischer, Stuttgart, p 195-203

Shiyatov SG (2003) Rates of change in the upper treeline ecotone in the Polar Ural mountains. PAGES News 11:8-10

Sitko I, Troll M (2008) Timberline changes in relation to summer farming in the western Chornohora (Ukrainian Carpathians). Mt Res Dev 28:263-271

Skre O, Wertz B, Wielgolaski FE, Szydlowska P, Karlsen SR (2017) Bioclimatic effects on different mountain birch populations in Fennoscandia. Clim Res 73:111-124

Solberg B, Tømmervik H, Thannheiser D, Neuvonen S (2005) Economoc limits and possibilities for sustainable utilization of northern birch forests. In: Wielgolaski FE (ed) Plant ecology, herbivory and human impact in
Nordic mountain birch forests. Ecological Studies 180. Springer-Verlag, Berlin, p 219-233

Speed JDM, Austrheim G, Hester AJ, Mysterud A (2010) Experimental evidence for herbivore limitation of the treeline. Ecology 91:3414-3420

Speed JDM, Austrheim G, Hester AJ, Mysterud A (2012) Elevational advance of alpine plant communities is buffered by herbivory. J Veg Sci 23:617-625

Stöcklin J, Körner C (1999) Recruitment and mortality of Pinus sylvestris near the Nordic treeline: the role of climate change and herbivory. Ecol Bull 47:168-177

* Strebel N, Bühler C (2015) Recent shifts in plant species suggest opposing land-use changes in alpine pastures. Alp Bot 125:1-9

Sveinbjörnsson B, Hofgaard A, Lloyd A (2002) The natural causes of the taiga-tundra boundary. Ambio Spec Rep $12: 23-29$

Tasser E, Tappeiner U (2002) Impact of land use changes on mountain vegetation. Appl Veg Sci 5:173-184

* Tasser E, Walde J, Tappeiner U, Teutsch A, Noggler W (2007) Land-use changes and natural reforestation in the Eastern Central Alps. Agric Ecosyst Environ 118:115-129

* te Beest M, Sitters J, Ménard CB, Olofsson J (2016) Reindeer grazing increases summer albedo by reducing shrub abundance in Arctic tundra. Environ Res Lett 11:125013

ten Houte de Lange SM (1978) Zur Futterwahl des Alpensteinbocks (Capra ibex L.). Eine Untersuchung an der Steinwildkolonie am Piz Albris bei Pontresina. Z Jagdwiss 24:113-138

Tenow O (1972) The outbreaks of Oporinia autumnata Bkh. and Operophthera spp. (Lep., Geometridae) in the Scandinavian mountain chain and northern Finland 1862-1968. Zoologiska Bidrag från Uppsala Suppl 2

* Tenow O, Nilssen AC (1990) Egg cold hardiness and topoclimatic limitations to outbreaks of Epirrita autumnata in northern Fennoscandia. J Appl Ecol 27:723-734

* Tenow O, Nilssen AC, Bylund H, Hogstad O (2007) Waves and synchrony in Epirrita autumnata/Operophtera brumata outbreaks. I. Lagged synchrony: regionally, locally and among species. J Anim Ecol 76:258-268

Tinner W, Theurillat JP (2003) Uppermost limit, extent, and fluctuations of the timberlines and treeline ecocline in the Swiss Central Alps during the past 11500 years. Arct Antarct Alp Res 35:158-169

* Tinner W, Ammann B, German P (1996) Treeline fluctuations recorded for 12500 years by soil profiles, pollen, and plant macrofossils in the Central Swiss Alps. Arct Alp Res 28:131-147

*Tolvanen A, Kangas K (2016) Tourism, biodiversity and protected areas-Review from northern Fennoscandia. J Environ Manage 169:58-66

* Tømmervik H, Johansen B, Riset JA, Karlsen SR, Solberg B, Høgda KA (2009) Above ground biomass changes in the mountain birch forests and mountain heaths of Finnmarksvidda, northern Norway, in the period 1957-2006. For Ecol Manage 257:244-257

*Törn A, Tolvanen A, Norokorpi Y, Tervo R, Siikamäki P (2009) Comparing the impacts of hiking, skiing and horse riding on trail and vegetation in different types of forest. J Environ Manage 90:1427-1434

* Treml V, Chuman T (2015) Ecotonal dynamics of the altitudinal forest limit are affected by terrain and vegetation structure variables: an example from the Sudetes Mountains in Central Europe. Arct Antarct Alp Res 47:133-146 * Treml V, Šenfeldr M, Chuman T, Ponocna T, Decová K 
(2016) Twentieth century treeline ecotone advance in the Sudetes Mountains (Central Europe) was induced by agricultural land abandonment rather than climate change. J Veg Sci 27:1209-1221

Turner H (1961) Die Niederschlags- und Schneeverhältnisse. Mitteilungen der forstlichen Bundes-Versuchsanstalt Mariabrunn 59:265-315

Turner H (1970) Grundzüge der Hochgebirgsklimatologie. In: Ladurner J, Purtscheller F, Reisigl H, Tratz E (eds) Die Welt der Alpen. Pinguin Verlag, Innsbruck, Umschau Verlag, Frankfurt, p 170-182

V Van Bogaert R, Haneca K, Hoogesteger J, Jonasson C, De Papper M, Callaghan TV (2011) A century of tree line changes in sub-arctic Sweden shows local and regional variability and only minor influence of 20th century climate warming. J Biogeogr 38:907-921

*Vittoz P, Camenisch M, Mayor R, Miserere L, Vust M, Theurillat JP (2010) Subalpine-nival gradient of species richness for vascular plants, bryophytes and lichens in the Swiss Inner Alps. Bot Helv 120:139-149

Weisberg PJ, Shandra O, Becker ME (2013) Landscape influences on recent timberline shifts in the Carpathian Mountains: abiotic influences modulate effects of landuse change. Arct Antarct Alp Res 45:404-414

Wielgolaski FE (1998) Twenty-two years of plant recovery after severe trampling by man through five years in three vegetation types at Hardangervidda. NTNU Vitenskapsmuseet Rapport Botanisk Serie 4:26-29

Wielgolaski FE (ed) (2001) Nordic mountain birch eco-

Editorial responsibility: Mikhail Semenov,

Harpenden, UK systems. Man and the Biosphere Series 27. Parthenon Publishing-UNESCO, Paris

*Wielgolaski FE (2003) Climatic factors governing plant phenological phases along a Norwegian fjord. Int J Biometeorol 47:213-220

Wielgolaski FE (ed) (2005) Plant ecology, herbivory, and human impact in Nordic mountain birch forests. Ecological Studies 180. Springer-Verlag, Berlin

Wielgolaski FE, Inouye DW (2013) Phenology at high latitudes. In: Schwartz MD (ed) Phenology: an integrative environmental science. Springer-Verlag, New York, NY, p 225-247

Wielgolaski FE, Karlsen SR (2007) Some views on plants in polar and alpine regions. Rev Environ Sci Biotechnol 6: 33-45

Wielgolaski FE, Nilsen J (2001) Coppicing and growth of various provenances of mountain birch in relation to nutrients and water. In: Wielgolaski FE (ed) Nordic mountain birch ecosystems. Man and the Biosphere Series 27. Parthenon Publishing-UNESCO, Paris, p 77-92

Wilmanns O (1989) Die Buchen und ihre Lebensräume. Ber Reinh-Tüxen-Ges 1:47-72

* Ylisirniö AL, Allén A (2016) Plant communities of Fennoscandian subarctic mountain ecosystems 60 years after human disturbance. Arct Antarct Alp Res 48:469-483

Z Zong C, Wauters LA, Dongen SV, Mari V and others (2010) Annual variation in predation and dispersal of Arolla pine (Pinus cembra L.) seeds by Eurasian red squirrels and other seed-eaters. For Ecol Manage 260:587-594

Submitted: February 16, 2017; Accepted: May 15, 2017 Proofs received from author(s): August 3, 2017 